\title{
ПРАВО И ПОЛИТИКА
}

\section{ЕВРАЗИЙСКИЕ ОСНОВЫ МЕЖДУНАРОДНО-ПРАВОВОЙ ПОЛИТИКИ РОССИЙСКОЙ ФЕДЕРАЦИИ}

ВВЕДЕНИЕ. ЭФфективность внешней, в том числе международно-правовой политики любого государства, зависит в том числе от ее научности, кониептуальной обоснованности, опорь как на понимание объективных законов мирового развития, так и на точную оченку места и роли соответствуюшего государства в этом процессе. Создание такой кониепции должно быть основано на синтезе природных, социально-экономических, политических и культурных факторов, характеризуюших состояние страны, на оченке ее участия в международном разделении труда, совместных проектах и программах развития, ее роли в обеспечении устойчивого развития и в глобализаиионных проиессах.

МАТЕРИАЛЫ И МЕТОДЫ. В статье анализируются доктрины и тендениии международноправовой политики Российской Федерации, находямей выражение прежде всего в международных договорах нашей страны, политико-правовых заявлениях руководителей государств, а также в политико-правовой практике межгосударственных отношений. При проведении исследования использовались общенаучные методь: историческиц̆, формально-юридическиц, системный анализ, сравнительное правоведение и др. Помимо данных науки международного права, использовались научные категории и конструкиии других общественных наук (историособии, политоло- гии, социологии, теории и истории государства и права).

РЕЗУЛЬТАТЫ ИССЛЕДОВАНИЯ. Проведенное исследование позволило прийти к выводу, что одним из основных кониептов современной международно-правовой политики являются положения классической евразийской доктрины. Геополитический кониепт Россия - Евразия призван обеспечить баланс западного и восточного векторов правовых основ внешней политики страны, предопределяет всю ее политическую историю, обусловливает приниипы и стандарты современной жизнедеятельности. Большое значение для внешнеполитической доктрины России, ее международно-правовой потитики имеет евразийский постулат о «месторазвитии» нашей странь, особенностях ее культурь, существовании циивилизационной общности. Цивилизационньй подход к оиенке потенииала России - Евразии должен лежать в основе определения масштабов и характера внешней политики России. По своему историческому масштабу наша страна не может рассматриваться как региональная держава даже несмотря на проблемы и трудности современного этапа ее развития. Евразийская доктрина, основные постулаты которой нашли отражение в кониепции внешней политики Российской Федераиии, помогает выработать правильные подходы к решению современных проблем мирово- 
го развития, в частности, таких вызовов, как глобализация, модернизация, всплеск идеологии национализма и т. д.

ОБСУЖДЕНИЕ И ВЫВОДЫ. Обсуждение кониептуальных правовых основ внешней политики Российской Федерации в научной литературе зачастую носит фрагментарныц характер и осуществляется в отрьве от поиска национальной идеи России. Различие подходов к решению данной проблемь в значительной степени затрудняет выработку обициальной международно-правовой доктрины внешнеполитического курса страны, не дает возможности четко определить ее национальные интересь. Очевидно, что обсуждение двух названных проблем должно осуществляться в рамках единого познавательного процесса. Национальная идея должна, с одной сторонь, стать базовой категорией кониепиии международно-правовой политики России, а с другой - конечным результатом ее творческого развития. Практическая реализация евразийского проекта потребу- ет от нашей страны внесения серьезных корректив во внешнюю политику, обеспечения ее разновекторности, поиска баланса между Востоком и Западом в дипломатический, политический, гуманитарной, правовой и иных сферах.

КЛЮЧЕВЫЕ СЛОВА: евразийская доктрина, Россия - Евразия, евразийская многонародная наичя, евразийский полицентризм мира, международньий правопорядок, евразийская правовая интеграция, Евразийский экономический союз

ДЛЯ ЦИТИРОВАНИЯ: Скуратов Ю.И. 2021. Евразийские основы международно-правовой политики Российской Федерации. - Московский журнал международного права. № 1. С. 28-45. DOI: https://doi.org/10.24833/0869-0049-2021-1-28-45

Автор заявляет об отсутствии конфликта интересов.

\section{LAW AND POLITICS}

DOI: https://doi.org/10.24833/0869-0049-2021-1-28-45

Research article Received 20 December 2020 Approved 28 February 2021

\section{Yuri I. SKURATOV}

Russian State Social University

4-1, ul. Wilhelma Pika, Moscow, Russian Federation, 129226

skuratov_yi@mail.ru

ORCID: 0000-0002-2126-2005

\section{EURASIAN BASIS OF THE INTERNATIONAL LEGAL POLICY OF THE RUSSIAN FEDERATION}

INTRODUCTION. One of the conditions for the effectiveness of the foreign policy of any state, including its international legal policy, is its scientific character, conceptual validity, reliance on understanding both the objective laws of world development and an accurate assessment of the place and role of the respective state in this process. The creation of such a trend should be based on the synthesis of natural, social, economic, political and cultural factors that characterize the state of the country, an assessment of its participation in the international division of labor, joint projects and development programs, its role in ensuring sustainable development and globalization processes.

MATERIALS AND METHODS. The article analyzes the doctrines and tendencies of the foreign policy of the Russian Federation, international treaties of Russia, statements by the leaders of states, as well as the political practice of interstate relations. During the research 
general scientific methods were used: system analysis, historical, formal - legal, comparative, etc. In addition to the materials of the doctrine of international law, scientific categories and constructions of other social sciences (historiosophy, political science, sociology, theory and history of state and law) were used.

RESEARCH RESULTS. The study made it possible to come to the conclusion that one of the main concepts of modern international politics is the provisions of the classical Eurasian doctrine. The geopolitical concept of Russia - Eurasia is designed to ensure a balance between the western and eastern vectors of the country's foreign policy, predetermines its entire political history, determines the principles and standards of modern life. Of great importance for the foreign policy doctrine of Russia is the Eurasian postulate about the "local development" of our country, the peculiarities of its culture, the existence of a civilizational community. A civilizational approach to assessing the potential of Russia - Eurasia should underlie the determination of the scale and nature of Russia's foreign policy. In terms of its historical scale, our country cannot be regarded as a "regional power" even despite its problems and difficulties of the current stage of development. The Eurasian doctrine, the main postulates of which are reflected in the foreign policy concept of the Russian Federation, makes it possible to find the right approaches to solving modern problems of world development, in particular, such challenges for our country as globalization, modernization, the ideology of nationalism, etc.

DISCUSSION AND CONCLUSIONS. The discussion of the conceptual base of the foreign policy of the

\section{1. Введение}

K онцепция внешней политики любой страны определяется прежде всего тем, как она позиционирует себя в современном мире, какой видит свою роль, место в планетарной системе координат. Это место определяется экономической и военной мощью государств и их союзов, численностью населения, научнотехнической оснащенностью, владением передовыми технологиями и т. д. Вместе с тем крайне значимую роль в борьбе за мировое лидерство играет идейная состоятельность тех или иных субъектов международной политики. Мировые игроки, имеющие претензии на глобальное лидерство, предлагают проекты (модели) грядущего мироустройства и своего места в нем. Такие
Russian Federation in the doctrine is fragmentary, often carried out in isolation from the search for the national idea of Russia. The difference in approaches to solving this problem significantly complicates the development of an official doctrine of the country's foreign policy and does not make possible to clearly define its national interests.

It is obvious that the discussion of these problems should be carried out within the framework of a single cognitive process, the national idea should, on the one hand, become the basic category of the concept of Russia's foreign policy, and on the other, the final result of its creative development. The practical implementation of the Eurasian project by Russia will require making serious adjustments to the country's diplomacy, ensuring its multi-directional, western and eastern balance in the diplomatic, political, humanitarian, legal and other scopes of life.

KEYWORDS: Eurasian doctrine, Russia - Eurasia, Eurasian multinational nation, Eurasian polycentrism of the world, international legal order, Eurasian legal integration, Eurasian Economic Union

FOR CITATION: Skuratov Yu. I. Eurasian Basis of the International Legal Policy of the Russian Federation. - Moscow Journal of International Law. 2021. No. 1. P. 28-45. DOI: https://doi.org/10.24833/08690049-2021-1-28-45

The author declares the absence of conflict of interest.

проекты можно назвать панидеями - идеямиконцепциями, которые, как отмечал еще более ста лет назад немецкий геополитик К. Хаусхофер, провозглашают большие цели и становятся жизненными формами будущего [Хаусхофер 2001:253].

В современных условиях можно выделить:

- панамериканскую идею, которая выступает как символ нового мирового порядка и глобализации по американскому образцу;

- панъевропейскую идею Большой Европы, позиционирующей себя как мощный центр силы, обладающий огромными потенциями в экономической, гуманитарной и других областях; - панкитайскую идею, ставящую целью объединение Великого Китая, модернизацию экономики, превращение Китая в сверхдержаву; 
- панисламскую идею, строящуюся на уверенности в неизбежном расширении мусульманского мира и создании Всемирного халифата.

Можно говорить и о других панидеях, в частности японской, предлагающей обгоняющее развитие [Буянов 2009: 7].

В этой связи В. Буянов отмечает, что «Россия не может влиться ни в один из названных цивилизационных проектов: это не позволит ни российская идентичность, ни ее собственные амбиции. Россия сегодняшних дней более близка к евро-американской модели «прогресса». Но парадигма «догоняющего» развития чрезвычайно опасна, ибо все больше ставит под вопрос субъектность России, грозит превращением ее в объект хозяйствования лидирующих стран Запада» [Буянов 2009:8; Kazharski 2013:7]. В этой же связи нельзя пройти мимо высказывания известного геополитика 3. Бжезинского о том, что «сделанный Россией... выбор... предоставил Западу стратегический шанс. Он создал предпосылки для прогрессирующей геополитической экспансии западного сообщества все дальше и дальше вглубь Евразии... и, в первую очередь, в некогда заповедную зону российского ближнего зарубежья» [Бжезинский 2008:214]. В Москве, похоже, наконец-то осознали, что в главных структурах Европы - Евросоюзе и НАТО - никто Россию не ждет. Она просто не поместится туда ни экономически, ни политически, ни географически. В том числе и поэтому можно, на наш взгляд, согласиться с утверждением, что «чисто западническая линия для России исчерпана» [Иванова 2007:382], хотя многие российские политики с этим могут поспорить.

С учетом всего сказанного В. Буянов полагает, что Россия в состоянии выработать и реализовать собственную концепцию развития, идущую в русле ее идентичности и имеющую глобальный характер. Эту концепцию все чаще обозначают как "русский мир», суть ее сводится к консолидации вокруг России всех русскоговорящих людей, проживающих в ближнем и дальнем зарубежье, к использованию их научного, культурного, социального потенциала для утверждения ведущей роли отечества в мировом сообществе [Буянов 2009:7-22].

Несколько иной подход к формированию идейных основ современной внешней политики России предлагают авторы монографии «Национальная идея России». Они полагают, что способами позиционирования страны в геополитическом пространстве могут быть либо идеология, либо национальная идея, акцентирующая систему национальных ценностей данной страны. А поскольку идеология достаточно неустойчивое явление, распространяющее свое влияние не больше, чем на три-четыре поколения людей, России, чтобы не раствориться в процессе глобализации и не потерять государственный суверенитет и идентичность, необходимо опираться на ценностный концепт, аутентичный собственному генетическому коду, своей истории и миссии в глобальном мире [Якунин и др. 2012:3735]. Этот позиционный концепт должен, по мнению авторов, отвечать следующим требованиям: иметь позитивный и конструктивный характер; отражать духовно-нравственные ценности, исторические и культурные коды страны, специфику ее политической и экономической системы; быть понятием содержательно простым и одновременно емким, привлекательным, чтобы его могли принять и поддержать представители всех наций, всех народов поликультурной и многоконфессиональной страны; обладать мобилизационной силой, вызывать у людей желание участвовать в его реализации; способствовать самоидентификации страны и нации, давать ответы на вопросы: кто мы? зачем мы? чем мы отличаемся от других? [Якунин и др. 2012:37363739]?

Исходя из этих принципов, авторы предлагают варианты возможного позиционирования России:

- либеральный концепт;

- коммунистический концепт;

- социал-демократический концепт;

- евразийский концепт;

- конфессиональный концепт;

- национальный концепт;

- цивилизационный концепт.

Проводя сопоставление потенциалов этих концептов, авторы отмечают определенную перспективу для евразийского концепта, но акцентируют внимание на двух его недостатках. Во-первых, эта идея содержит жесткое противопоставление России как евразийской страны Западу, закладывает определенную стратегическую уязвимость. Действительно, для России характерны довольно большие отличия от англо-саксонской модели по целому ряду серьезных параметров, однако при этом она имеет и признаки европейской цивилизации. Во-вторых, евразийская идея характеризуется сложностью прочтения, полисемантикой смысла. Есть и важная семантическая и сущностная слабость этой 
идеи, вытекающая из ее несамоопределенности, некой вторичности, гибридизации, в контексте которой евразийство - нечто подчиненное, перемешанное из базовых ингредиентов... [Якунин и др. 2012:3737-3738]. В заключение авторы делают вывод: «несомненно заслуживающая внимания идея является достаточно чуждой широким массам населения и не обладает для них нужной степенью аутентичности и аттрактивности» [Якунин и др. 2012:3738]. В итоге авторы высказываются в пользу цивилизационного концепта, который «отвечает необходимым требованиям и принципам. Он соответствует принципу аутентичности, так как имеет в виду уникальную, самобытную цивилизацию великой державы, акцентирует особость, неповторимость исторического пути и миссии России, позволяет четко позиционировать страну в условиях многополярного мира» [Якунин и др. 2012:3738].

Отмечая в целом оправданное желание как названных выше, так и многих других авторов сформулировать своего рода национальную идею страны, обеспечивающую ее позиционирование в глобальном мире, следует высказать некоторые сомнения в пригодности для этой роли предлагаемых ими вариантов.

При всей актуальности и значимости стратегии "русского мира», направленной на консолидацию русскоговорящих вокруг России, поддержку русской культуры и языка, на эффективную работу с диаспорой, евразийский проект России более масштабен, поскольку опирается на духовную культуру не только русского народа, но и других народов России, а также Евразии в целом. Этот проект более органичен для России и с точки зрения его наднациональной, общецивилизационной природы. Естественно, что русской культуре и русскому языку в евразийском проекте принадлежит ключевая роль.

Позиция, отдающая предпочтение так называемому цивилизационному концепту в ущерб евразийскому, представляется спорной. Во-первых, недопустимо противопоставление этих концептов. Евразийский подход, как мы уже отмечали, и есть по своей сути общецивилизационный подход, базирующийся на идее существования России - Евразии как особой цивилизации, не сводимой ни к европейской, ни к азиатской, ни к какой другой. Во-вторых, по степени конкретности постановки вопроса цивилизационный концепт еще более абстрактен, чем евразийская идея, придающая уже своим названием определенную геополитическую на- правленность цивилизационной доминанте России. В-третьих, евразийская идея России опирается на стройную, основательно проработанную комплексную концепцию, доктрину, сохранившую свою актуальность и подтвердившую на практике достоверность своих прогностических элементов. Общецивилизационная концепция России в значительной степени отстает от уровня завершенности разработки евразийской идеи, она в целом представляет довольно разновекторный конгломерат подходов, течений, идей, взглядов. В этих рамках уместились и проводимая в перестроечный и постсоветский периоды политика заимствования общечеловеческих ценностей, оказавшихся по сути чисто западными идеалами, и прямой перенос на российскую почву крайне либеральных взглядов и конструкций, и некоторое наблюдаемое в последнее время охлаждение интереса к этим идеям, попытка найти выход в православной вере и т. д. Поэтому, на наш взгляд, нужно не противопоставлять эти два вектора развития отечественной научной мысли, а обеспечить новый исторический синтез, который позволит углубить и адаптировать каждый из них применительно к условиям современной России.

В-четвертых, вряд ли можно согласиться с упреком в адрес евразийцев из-за их антизападнического настроя. Эта тема достаточно широко используется в спекулятивных целях критиками евразийства как научного течения. Да, безусловно, в ряде публикаций евразийских авторов можно найти резкие, нелицеприятные оценки европейского Запада, высказанные в пылу полемики при обсуждении политики западной экспансии в Россию и т. д. Иное дело, когда речь идет о принципиальной позиции. Да и самый глубокий смысл евразийства состоит в историческом синтезе начал европейской и азиатской культур, который исключает какое-либо оголтелое антизападничество.

В-пятых, нельзя согласиться и с упреками в адрес евразийства относительно его «несамоопределенности», некой вторичности, «гибридизации», его «подчиненности», «перемешанности базовых ингредиентов». Интересно было бы посмотреть, какую мировую культуру авторы считают чистой, неперемешанной и негибридной? Примечательно в этой связи высказывание П. Н. Савицкого, которое характеризует его понимание евразийской культуры: «Новую культуру, - писал он, - можно смешивать со старыми и счесть простой комбинацией их элементов толь- 
ко в том случае, если мы, стремясь ее познать, смотрим не на ее субъект, а на еще не освоенный им строительный материал - на окружающую его среду и на еще не переваренные им инородные тела. Когда мы говорим об " элементах" культуры, о ее "заимствованиях" и о "влиянии" на нее, мы делаемся жертвой поверхностных наблюдений, принимая за свойственное культуре то, что еще ею не освоено, или называя чужим то, что когда-то было чужим, но зато и совсем другим. С внешней точки зрения нет самостоятельных культур, ибо ни одна из известных нам не свалилась готовой с неба, но все родились в какойто уже существовавшей среде других культур. Но по существу всякая культура в собственном смысле этого слова самобытна и рождается как нечто абсолютно новое и специфическое, что мы и выражаем, когда говорим об "идее" или "духе" данной культуры» [Савицкий 1997:21]. И далее: «Весь смысл и пафос наших утверждений сводится к тому, что мы осознаем и провозглашаем существование особой евразийско-русской культуры и особого ее субъекта как симфонической личности. Нам уже недостаточно того смутного культурного самосознания, которое было у славянофилов, хотя мы и чтим их как наиболее нам по духу близких. Но мы решительно отвергаем существо западничества (не Запада как такового. - Ю.С.), т. е. отрицание самобытности и, в конце концов, самого существования нашей культуры» [Савицкий 1997:20-21].

И, наконец, последнее. Можно отчасти согласиться с тем, что для распространения евразийской идеи ей не всегда хватает аутентичности и привлекательности. Такого рода замечания касаются любого из современных российских концептов, о чем косвенно свидетельствует отсутствие в нашем обществе национальной идеи, консолидирующей большинство российских граждан. Вместе с тем, в силу отмеченного выше комплексного, разностороннего характера евразийского учения, вполне могут быть выделены отдельные идеи, носящие довольно привлекательный и близкий к менталитету россиян характер. Таким, например, может служить положение программного документа евразийцев о том, что «евразийское государство является государством трудящихся, государством социальной справедливости и правды» [Россия на пороге...1996:40]. Весьма привлекательна и идея братства народов Евразии, которая, по сути, выполняет роль главного постулата этой концепции.
Нельзя при этом не учитывать и то обстоятельство, что новейшая постиндустриальная эпоха радикальным образом отличается от эпохи индустриализма, когда создавалось евразийство. В этом один из его недостатков и известная историческая ограниченность. Жизнь современного общества определяется такими обстоятельствами, которых не было сто лет назад. Поэтому наша задача состоит в том, чтобы не только сохранить, но и развить основные, выдержавшие испытания временем идеи уникальной концепции.

Ключевое значение для успешности евразийского проекта России будет иметь разработка алгоритма развития, отличного от развития догоняющего. Догнать и даже перегнать Запад в каких-то отраслях случалось, и не однажды. Но найти совершенно новую парадигму коренной модернизации удалось лишь раз - в результате коммунистического эксперимента. Можно его по-разному оценивать, но не следует забывать, что на протяжении ряда десятилетий СССР был историческим лидером, внесшим решающий вклад в разгром фашизма, открывшим космическую эру, больше других способствовавшим деколонизации мира [Буянов 2009:11]. При любом отношении к социальной модели нашего бывшего государства очевидно, что сам факт его существования, масштаб деятельности, влияние на мировое развитие еще долгое время будут сказываться на внешней и внутренней политике современной России.

\section{2. Основные положения евразийской концепции в контексте международной политики России.}

Какие же постулаты классической евразийской концепции имеют наиболее важное значение для современной международной политики РФ?

Очевидно, что прежде всего речь должна идти об обоснованных евразийцами особенностях географического положения, определяющего геополитическое позиционирование России Евразии. По мнению А. Г. Дугина, евразийцы, и прежде всего П. Н. Савицкий, были первыми российскими учеными, освоившими это направление науки об обществе. «Оппозиция Востока и Запада, буржуазного меркантилизма и либерализма, с одной стороны, и идеократических форм - с другой, прекрасно осознавалась и осмыслялась евразийцами» [Дугин 1997:255]. 
Евразийская геополитика представляет собой концептуализацию стратегических, культурных и духовных интересов русских земель как «географической оси истории». «У евразийцев "ось истории" обретает свой голос, пронзительно и однозначно заявляет о себе» [Дугин 1997:255].

Геополитический концепт «Россия - Евразия», связанный с обеспечением баланса западного и восточного векторов ее внешней политики, предопределяет всю политическую историю страны, а также обусловливает и современные императивы ее международной жизнедеятельности. «История последних двух столетий свидетельствует, - справедливо отмечает М. Л. Титаренко, - что любые попытки российской политики действовать, склоняясь в одну сторону, будь то к Европе или Востоку, неизбежно ведут к раскачке фундамента общества и подрывают основы культурной идентичности народов, лишают страну гибкости в принятии ключевых решений о своем будущем. Лишь осознание неразрывной целостности двух важнейших сторон государственной идентичности, т. е. западной и восточной, позволяет России уверенно и стабильно двигаться вперед, сохранять добрые отношения сотрудничества и соразвития между всеми народами, населяющими нашу страну» [Титаренко 1998:88].

Важное значение для внешнеполитической доктрины России имеет евразийский постулат о месторазвитии нашей страны как неотъемлемой характеристике ее географического и геополитического статуса в мире. Всесторонняя и детальная разработка данной категории как уникального сплава природных, социально-экономических и культурных факторов по праву может претендовать на научное открытие мирового значения. Не повторяя уже высказанные соображения на этот счет, заметим, что учет природных особенностей и социально-экономического обустройства территории государства (России) крайне важен не только для внутреннего развития страны, но и для международного сотрудничества ${ }^{1}$. Речь идет об участии в международном разделении труда, о совместных экономических проектах и программах, о международной торговой деятельности и т. д.

Крайне важную роль фактора внешнеполитической деятельности современной страны играет евразийский концепт, связанный с пониманием
России - Евразии как особого, самостоятельного культурного мира. Именно евразийцам принадлежит ряд важных для современного международного права подходов относительно понимания роли культуры как фактора цивилизационного развития. Речь идет о самобытной ценности культур всех народов, об отсутствии иерархии в оценке этих культур, об опасности утраты самобытной культуры народов и их духовной деградации при попытках насильственного приобщения «отсталых народов к благам цивилизации в процессе европеизации» [Трубецкой 2015:27] и т. д.

Соответствующий методологический подход позволил евразийцам развить идею Н. Я. Данилевского и славянофилов о полицентризме мира, утверждающую, что мир состоит не из мирового центра (как правило, Западной Европы) и остальной периферии, а из ряда равноправных центров-цивилизаций, к числу которых относится и Россия - Евразия. Каждый из этих центров самодостаточен, отличается выраженным своеобразием и историческим опытом и должен развиваться через самопознание населяющих его народов и тем самым осуществлять свое назначение на земле [Россия на пороге...1996:25]. Идея полицентризма отрицает и существование универсального процесса, а также линейность исторического развития. В дальнейшем она была развита в трудах Л. Н. Гумилева, обосновавшего концепцию этногенеза, т. е. этнического развития цивилизаций (этносов, суперэтносов) [Кендердайн 2020:258-268].

Синтез географического (геополитического) подхода к пониманию роли России - Евразии в мире, исследования ее месторазвития, а также особенностей культуры дали евразийцам основания вести речь о существовании на ее просторах особой цивилизационной общности. Стержнем этой цивилизационной общности выступает внутреннее единство и целостность культуры. Россия, «как и другие многонародные культурные единства, индивидуализирует человечество, являя его единство во взаимообщении с ними, и потому, осуществляя себя, осуществляет свою общечеловеческую, "историческую миссию"» [Россия на пороге...1996:22]. Цивилизационный подход к оценке сути и одновременно потенциала России -

\footnotetext{
1 Так, П.Н. Савицкий, в частности, отмечает, что естественные богатства Евразии и их распределение открывают ей путь к экономическому самодавлению и превращают её в континент-океан [Савицкий 1997:21].
} 
Евразии должен лежать в основе оценки масштабов и характера внешней политики современной России. Отсюда следует, что и по своему историческому масштабу Россия определенно не может рассматриваться как региональная держава, даже несмотря на наличие проблем и трудностей современного государственного строительства.

Важнейшее положение евразийской доктрины связано с оценкой особой роли русского народа, русской культуры в России - Евразии. Недобросовестные критики евразийства приписывают ему недостаточную «русскость», недооценку значимости великорусского начала в основных постулатах этой концепции [Нарочницкая, Мяло 1995:128-137]. Между тем особая роль русского народа и его культуры выступает отправной точкой теоретических построений и практических выводов классического евразийства. «Определяя русскую культуру как евразийскую, - отмечает П. Н. Савицкий, - евразийцы выступают как осознаватели русского культурного своеобразия. В этом отношении они имеют еще больше предшественников, чем в своих чисто географических определениях. Таковыми в данном случае можно признать всех мыслителей славянофильского направления, в том числе Гоголя и Достоевского (как философов-публицистов). Евразийцы в целом ряде идей являются продолжателями мощной традиции русского философского и историософского мышления» [Савицкий 1997:44]. Поэтому, с одной стороны, без определяющей, стержневой роли русского народа бессмысленны все евразийские построения и конструкции. С другой - без евразийства невозможно адекватно оценить роль русского народа, русского начала в мировой истории. Отсюда следует, что современные внешнеполитические доктрины России («русский мир», «русская доктрина» и др.), ориентированные на придание нового импульса развитию русского этноса, также имеют евразийские корни.

Для выстраивания модели внутренней и внешней политики современной России крайне значимую роль играют евразийские подходы к формированию нового типа межнациональных и межконфессиональных отношений в пределах России - Евразии. «Важнейшей стороной евразийской концепции, помимо географичности, является ее этнологичность. Основоположники евразийского учения не только уделяли боль- шое внимание этническим проблемам России, но и превратили этническую составляющую в один из стержней своей концепции» [Россия на пороге...1996:26]. Важнейшим фактором, благодаря которому в пределах евразийского пространства был накоплен уникальный опыт межнационального и межконфессионального сотрудничества, стала русская культура. «Русская культура, - справедливо отмечают авторы фундаментального труда "Русская доктрина", это высочайшая культура усвоения социальных ценностей. Русские, усваивая культурные богатства различных традиций, предпочитают ни от чего не отказываться, ни от чего не отрекаться. Благодаря этому качеству нашей культуры в России может ужиться все ценное, что выработало человечество» [Русская доктрина ...2008: 29-30]. Введенная евразийцами задолго до современных научных разработок категория «российская (евразийская) многонародная нация» в концентрированном виде отражает высочайшие стандарты межнационального согласия, взаимного учета интересов. Поскольку внешняя политика есть, по сути, предложение внутренней, то очевидно стремление России культивировать эти же ценности и принципы в своих международных делах, во взаимоотношениях с другими народами и государствами.

Вполне очевидно, что названые выше постулаты евразийской теории при желании вполне легко и органично могут быть трансформированы в систему принципов внешней политики современной России. В этой связи в научной литературе справедливо отмечается, что сегодня исключительно актуальна проблема того, в какой мере евразийский проект подходит для решения конкретных задач, стоящих перед Россией [The Law and Policy ... 2021:634-636]. Иначе говоря, необходимо выяснить, может ли евразийство как доктринальное учение выступать базой, основой для интегральной теории развития современной Российской Федерации или, напротив, лишь отдельные ее составляющие окажутся подходящими для включения в принципиально иную по духу теорию. Последнюю, разумеется, можно в политических целях назвать евразийской (неоевразийской), но она будет иметь с первоначальным (доктринальным) учением лишь внешнее и отдаленное сходство [Россия на пороге...1996:38-39]2.

\footnotetext{
2 Можно согласиться и с другим утверждением авторов: «Представляется, что российско-евразийская цивилизация, объединяющая многочисленные народы Восточной Европы и Азии, окончательно не сложилась ни к 1917 г., когда
} 
На сегодняшний день можно констатировать, что классическая евразийская концепция довольно выборочно, фрагментарно используется во внешней и в особенности во внутренней политике современной России. Прежде всего, это было свойственно для первого этапа развития страны как самостоятельного субъекта международного права, для которого был характерен явный крен в сторону некритического заимствования западных либеральных ценностей (вариант описанной евразийцами европеизации России). Поскольку Россия вступила на рыночный путь со значительным опозданием, ее конкуренты не просто ушли далеко вперед в области развития общественных институтов, а создали ситуацию, при которой массовое использование их моделей развития в прошлом зачастую делало невозможным успешное следование этим моделям в настоящем. В экономике это выражается в доказанности невозможности успешного догоняющего развития, в жизни - примером, когда колея на дороге углубляется и разбивается так, что пользоваться ею становится невозможно. Кроме того, развитые страны, пользуясь правом первооткрывателя и доминирующим политическим влиянием (которое при либеральных реформах 1990-х годов носило характер прямого внешнего управления), весьма последовательно проводили политику сдерживания России в выгодном для себя промежуточном состоянии, когда она не грозит соседям своим разрушительным и для них крахом, но не способна не только защищать, но даже и осознавать свои национальные интересы [Делягин 2002:31].

В последние годы наметилась тенденция выравнивания одностороннего уклона к западным либеральным ценностям, постепенного осознания исторической традиции и поиска идентичности страны во внутренней и внешней политике. Определенные надежды вселяет провозглашенная В. Путиным приверженность идеи евразийской интеграции ${ }^{3}$, а также последние акценты во внешней политике РФ.

Перестройка на евразийские рельсы происходит не всегда последовательно, общественно-политическое сознание меняется не столь быстро, как хотелось бы. Даже в важных концептуальных оценках наблюдаются спорные, не вписывающиеся в классическую евразийскую концепцию тезисы. Так, в одном из программных документов применительно к евразийскому вектору развития страны утверждается: «Евразийский союз открытый проект. Его развитие не противоречит европейскому выбору. Евразийский союз будет строиться на универсальных интеграционных принципах как неотъемлемая часть Большой Европы, объединенной едиными ценностями свободы, демократии рыночных законов» ${ }^{4}$. Вопервых, подлинно евразийская политика России исключает сугубо европейский выбор, поскольку имеет двухвекторную направленность: на Запад и Восток. Во-вторых, не бесспорно утверждение об универсальном характере интеграционных принципов ЕС и Евразийского союза. Интеграционные подходы могут, конечно, содержать общие моменты, но в целом они определяются спецификой субъектов интеграции, ее целями, задачами, степенью единения соответствующих сфер общественной жизни, а также традициями, культурой и т. д. Наконец, в-третьих, вполне очевидно, что ценности свободы, демократии и даже рыночных законов отличаются различным наполнением. И далеко не все европейские ценности воспринимаются евразийским сообществом народов и государств. При этом, конечно, крайне осторожно нужно отнестись и к получившему достаточно широкое распространение у политологов тезису о «Великой Европе от Лиссабона до Владивостока», который, по сути, стирает Евразию с политической карты мира. Именно в этом направлении подталкивает Россию и небезызвестный 3. Бжезинский: «Для России единственный геостратегический выбор, в результате которого она смогла бы играть реальную роль на международной арене и получить максимальную возможность трансформироваться и модернизировать свое общество, это Европа. И это не просто какая-нибудь Европа, а трансатлантическая Европа с расширяющимися ЕС и НАТО. Такая Европа... по-прежнему тесно связана с Америкой» [Бжезинский 1998:142143].

рухнула империя, ни к 90-м годам, когда рухнул Союз. Все это говорит о цивилизационной хрупкости России-Евразии» [Россия на пороге...1996:39]. Вместе с тем реальное развитие политической практики не всегда свидетельствует об ущербности самой идеи.

3 См.: Путин В.В. Новый интеграционный проект для Евразии - будущее, которое рождается сегодня. - Известия. 4.10.2011.

4 Там же. 
Вместе с тем следует констатировать, что за последние годы евразийский вектор внешней политики России становится все более очевидным. Утвержденная Указом Президента РФ от 30 ноября 2016 г. Концепция внешней политики Российской Федерации достаточно широко восприняла евразийские идеи и принципы 5

В концепции внешней политики, оценивающей современное состояние мира, отмечается, что он «переживает период глубоких перемен, сущность которых заключается в формировании полицентричной международной системы. Структура международных отношений продолжает усложняться. В результате процесса глобализации складываются новые центры экономического и политического влияния. Происходит рассредоточение мирового потенциала силы и развития, его смещение в Азиатско-Тихоокеанский регион. Сокращаются возможности исторического Запада доминировать в мировой экономике и политике. Отчетливо проявляется многообразие культур и цивилизаций в мире, множественность моделей развития государств» ${ }^{6}$. Данный тезис не только находится в полном соответствии с исповедуемой евразийцами идеей полицентричности мира, но и в значительной мере актуализирует давний их замысел о необходимости «поворота на Восток», развитии всесторонних экономических и культурных связей с этим цивилизационным полюсом, что позволит придать новый импульс обеспечению национальной безопасности России - Евразии, росту ее экономики и политического влияния в мире.

В целом, в соответствии с евразийскими установками о цивилизационной значимости России - Евразии и о полицентричности мира, концепция позиционирует Россию в качестве «одного из влиятельных центров современного мира» и ставит задачу по обеспечению безопасности страны, сохранению и укреплению ее суверенитета и территориальной целостности, прочных и авторитетных позиций в мировом сообществе для увеличения ее политического, экономического, интеллектуального и духовного потенциала. Однако, очевидно, что термин «один из влиятельных центров мира» достаточно абстрактен и предполагает разные степени влияния на мировую политику. Эта формула не исключает и роль России как мощной, но региональной державы. Вместе с тем нашей стране нужен «дееспособный» политический курс, который опирается на объективные геополитические и культурно-цивилизационные характеристики и идеологической основой которого может быть только евразийская стратегия как долговременный, многоуровневый геополитический проект. Принципы нового евразийства должны стать методологической и идейной основой долгосрочной стратегии развития и обустройства России, ее внешнеполитической доктрины [Титаренко 1998: 99].

\section{3. Многовекторная направленность внешней политики России}

В этой связи крайне важную роль приобретает изложенный в концепции внешней политики тезис: «Отличительная черта российской внешней политики - ее сбалансированность и многовекторность. Это обусловлено геополитическим положением России как крупнейшей евразийской державы, ее статусом одного из ведущих государств мира и постоянного члена Совета Безопасности ООН. Интересы страны в современных условиях диктуют настоятельную необходимость активного продвижения позитивной повестки дня по всему спектру международных проблем». Евразийские мотивы ощутимы и в положениях Концепции о восточном направлении внешней политики России: «В контексте многовекторной внешней политики Российской Федерации важное и всевозрастающие значение имеет Азиатско-Тихоокеанский регион, что обусловлено принадлежностью России к этому динамично развивающемуся району мира, заинтересованностью в использовании его возможностей при реализации программ экономического подъема Сибири и Дальнего Востока, необходимостью укрепления регионального сотрудничества в сфере противодействия терроризму, обеспечения безопасности и налаживания диалога между цивилизациями. Продолжится активное участие России в основных интеграционных структурах Азиатско-Тихоокеанского региона - форуме «Азиатско-Тихоокеанское экономиче-

\footnotetext{
5 См. Концепция внешней политики Российской Федерации. Утв. Указом Президента РФ от 30 ноября 2016 г. Доступ: http://www.kremlin.ru/acts/news/785 (дата обращения: 04.12.2020).

6 Там же.
} 
ское сотрудничество», механизмах партнерства с Ассоциацией государств Юго-Восточной Азии (АСЕАН), включая региональный форум $\mathrm{ACEAH».}$

Одним из ключевых факторов использования потенциала классического евразийства во внешней политике является интенсивное развитие сотрудничества с Китайской Народной Республикой [Бордачев, Пятачкова 2018:33-51]. В современных условиях нарастания противоречий с Западом, попыток с помощью различного рода санкций оказать экономическое давление на Россию сотрудничество с Китаем является не просто проявлением желаемого евразийцами «исхода к Востоку», но и фактором сохранения внутриполитической и экономической стабильности страны, обеспечения национальной безопасности. «Россия будет и дальше наращивать российско-китайское стратегическое партнерство во всех областях на основе совпадения принципиальных подходов к ключевым вопросам мировой политики в качестве одной из базовых составляющих региональной и глобальной стабильности. Главной задачей в области двусторонних связей является приведение объема и качества экономического взаимодействия в соответствие с высоким уровнем политических отношений», - говорится в названной выше Концепции внешней политики России.

Евразийский подход можно проследить и в других позициях Концепции внешней политики России. Развивая евразийскую концепцию полицентризма многополярного мира, Российская Федерация отвергает претензии США и Североатлантического альянса на мировое господство, отстаивает принцип суверенного равенства государств в международном сообществе [Robinson 2020:10-37]. Неприемлемы для России политическая, экономическая и культурная экспансия какого-либо из цивилизационных центров мира. В плане конкретизации этого подхода Концепция внешней политики отстаивает тезис о повышении управляемости мирового развития, но не за счет существования единого центра управления в лице какой-либо страны или группы (блока) самых «развитых» стран, а путем создания саморегулируемой международной системы, что требует коллективного лидерства ведущих государств мира, которое должно быть представительным в географическом и цивилизационном отношении и осуществляться при полном уважении к центральной и координирующей роли ООН. В этих целях «Россия будет наращивать взаимодействие в таких форматах, как «группа восьми» и ее диалог с традиционными партнерами, «тройка» (Россия, Индия, Китай), «четверка» БРИК (Бразилия, Россия, Индия, Китай), а также с использованием других неформальных структур и диалоговых площадок». Очевидно, что Россия с точки зрения и географического, и цивилизационного принципа вписывается в систему коллективного лидерства ведущих государств мира.

Евразийскую природу имеет и установка концепции о том, что «Россия как многонациональное и многоконфессиональное государство способствует диалогу и партнерству между культурами, религиями и цивилизациями, последовательно проводит эту линию в рамках ООН, ЮНЕСКО, ОБСЕ, Совета Европы и других международных и региональных организаций, в контексте с Организацией Исламская конференция; поддерживает соответствующие инициативы гражданского общества, активно взаимодействует с Русской православной церковью, другими основными конфессиями страны». С учетом идей евразийской интеграции в Концепции внешней политики России определены региональные приоритеты внешней политики страны: Союз России и Беларуси, ЕАЭС, СНГ, ШОС и др. [Arbatova 2019:7-24; Podadero 2017:40]. В контексте поддержки «русского мира» сформулированы подходы к взаимодействию с диаспорой. Предусмотрены механизмы участия республик других регионов России во внешнеполитической и внешнеэкономической деятельности и т. д.

Оценивая в целом Концепцию внешней политики России как важнейший доктринальный документ международно-правового характера, можно утверждать, что евразийство составляет одну из стержневых идей этого акта. Принципиально важно не утратить данный евразийский фактор-потенциал, закрепить и развить его в системе международно-правовых договоров, заключаемых на двусторонней и многосторонней основе и, что не менее важно, реализовать в повседневной внешнеполитической практике.

Основные постулаты и принципы евразийской доктрины дают возможность найти правильные подходы при решении современных проблем мирового развития, ставших весьма актуальными за последние десятилетия. Речь идет о таких вызовах для современной России, как глобализация, модернизация, всплеск идеологии национализма и т. д. 


\section{4. Экономическая составляющая международно-правовой политики России}

Глобализация, охватывающая все сферы жизни мирового сообщества, -глубоко противоречивый процесс. В нем есть элементы прогресса, в особенности технологического, объединения усилий всех стран во имя общих целей, имеющих планетарное значение (экология, борьба с эпидемиями и нищетой и т. д.). Вместе с тем в современных условиях речь идет о доминировании либеральной модели глобализации, идеологическим обоснованием которой является доктрина рыночного фундаментализма, исповедующая вредность государственного вмешательства в экономику и предписывающая демонтаж институтов госрегулирования для свободного движения капиталов [Глазьев 2016:3-29]7. Идеология либеральной глобализации обслуживает интересы имперского мирохозяйственного уклада, является инструментом экспансии США, претендующих на мировое господство. Отсюда в общей системе глобализации есть элементы неравенства, давления, экспансии сильнейших, а то и открытого насилия. Негативный аспект глобализации представляет собой современное состоянии формы империализма [Мартышин 2016:29]. Глобализация имеет не только экономическую составляющую. Либеральная идеология распространяется и на сферу политической и правовой культуры, реализуется под флагом демократии, прав человека и правового государства.

Проведение евразийского геополитического курса потребует от руководства страны соответствующей экономической политики. Сейчас уже понятно, что само по себе включение в процесс глобализации, встраивание в сеть мировой экономики автоматически не повлечет за собой модернизации страны. Не оправдана была бы и другая крайность в экономике - политика возрождения «железного занавеса», стремление закрыться, изолироваться от мировых процессов и тенденций. Необходим поиск золотой середины, интеграции в глобальную экономику с сохранением и укреплением суверенитета. Евразийская природа России связана с ее ролью преемницы СССР, сохранившей влияние на постсоветском пространстве. Можно согласиться с тезисом, что «евразийство в экономике возможно лишь при условии вхождения в глобализацию с сохранением контроля как минимум в масштабах постсоветского пространства. Задача наших геополитических оппонентов - включить это пространство в глобальную экономику по частям, с потерей ими своего суверенитета, задача России - интегрировать это пространство экономически и включить в мировую экономическую систему» [Дугин 2008:110].

Евразийскому подходу вполне соответствуют и предлагаемые в литературе методы противодействия либеральной глобализации. «Имперский мирохозяйственный уклад, который идеологически обслуживали доктрины рыночного фундаментализма, уступает место интегральному, чьей идеологической основой является системный подход к достижению гармонии интересов на базе роста общественного благосостояния и теория устойчивого развития» [Глазьев 2016:329]. Идеологическим фундаментом для нового миропорядка может стать концепция социально консервативного синтеза, объединяющая систему ценностей мировых религий с достижениями социального государства и научной парадигмой устойчивого развития [Глазьев 2006:71-76].

Трансформация евразийского учения в принцип внешней политики РФ предполагает учет и других аспектов общемировой тенденции глобализации, т. е. формирования общемирового и регионального экономического, информационного, социального и политического пространства. Этот процесс сопряжен с интернационализацией многих юридических институтов. Формирование новых экономических и иных отношений вне существующих государственных границ в различных сферах деятельности людей, организаций и государств происходит на основе права, т. е. в результате заключения различных рода соглашений, договоренностей между государствами или группами государств. Другими словами, одновременно с экономической глобализацией отчетливо наблюдаются процессы глобализации права, или юридической глобализации [Овчинников, Овчинникова 2002:13], которые требуют комплексной разработки. При этом не только происходит своеобразное давление норм международного права на национальные правовые

\footnotetext{
7 «На самом деле, - пишет С. Н. Бабурин, - современные теории глобализации в политическом плане понимают под этим термином интернационализацию и интеграцию экономической и всей общественной жизни с акцентом на признание универсальности западного общества и его пригодности в качестве образца для всех народов. В конечном счете под глобализацией подразумевается не что иное, как установление нового миропорядка» [Бабурин 2005:651].
} 
системы, но и, наоборот, международно-правовые стандарты формируются на базе наиболее эффективных и передовых норм и механизмов внутригосударственного права.

\section{5. Юридические основы евразийского подхода}

Вместе с тем оценка роли правового фактора в контексте евразийского подхода не сводится только к его задачам применительно к процессам глобализации. Речь идет о правовом обеспечении евразийского внешнеполитического курса России в целом. Представляется, что эта задача является комплексной, масштабной по своему объему и включает в себя:

а) обеспечение стабильности существующего международного правопорядка, исключение попыток ряда государств сломать сложившуюся систему международного права за счет переформирования ее на базе собственных, национальных правовых традиций;

б) активное участие в выработке универсального общецивилизационного правового порядка, приемлемого не только в области регулирования международных отношений, но и в качестве общепризнанного инструмента разрешения неизбежных коллизий на уровне межрегиональной кооперации;

в) активную роль в создании прочной международно-правовой основы для обеспечения интеграционных процессов в рамках Евразийского экономического союза;

г) обеспечение гармонизации международно-правовой базы евразийского вектора внешней политики России с внутренним национальным законодательством страны;

д) создание международно-правовой инфраструктуры для усиления восточного вектора международной политики России.

Часть важных задач в вопросе сохранения стабильного миропорядка была сформулирована Концепцией внешней политики России. Определена линия России на «укрепление правовых основ международных отношений, добросовестное соблюдение международно-правовых обстоятельств». Поддержание и укрепление международной законности - одно из приоритетных направлений деятельности нашей страны на международной арене. «Верховенство права в международных отношениях призвано обеспечить мирное и плодотворное сотрудничество государств при соблюдении баланса их интересов, а также гарантировать стабильность мирового сообщества в целом». Акцент на сохранении и укреплении международно-правовых основ миропорядка со стороны России вполне оправдан, поскольку его фундамент закладывался еще при существовании сверхдержавы - Советского Союза и отражает геополитические интересы современной Российской Федерации, пока не имеющей такого веса и влияния в мире [Lagutina 2014:96]. Вместе с тем существующая международно-правовая основа внешней политики страны дает определенную временную фору России для раскрытия ее огромного цивилизационного потенциала и обретения большего влияния на мировую политику.

Мировая экспансия проатлантистских режимов не только сводится к сфере экономики, но и ощутима в сфере противостояния правовых систем, одна из форм выражения которого связана с геополитическим различием евразийской (континентальной) и англо-саксонской правовых моделей. Регулирование имущественных прав, методики расчетов прибыли и прогнозирования рисков, осуществляемое на основе логики все более доминирующего в международных экономических отношениях англо-саксонского торгового права, ставит государства континентальной системы в своего рода неравноправное положение, ибо не позволяет аккумулировать капиталы с такой скоростью, как это происходит в случае англо-саксонской модели - гораздо менее институционально и психологически зависимой от консервативных факторов в национальной экономике. Все это напрямую связано с перспективами долгосрочной кредитно-денежной политики и вопросом об основной международной резервной валюте.

Евразийская правовая интеграция, обеспечивающая континентальную модель торгового общества, основанную не на спекулятивном подходе, а на обязательных и повсеместных инвестициях в базисную эколандшафтную инфраструктуру, должна дать симметричный ответ на вызов правовой традиции атлантизма, олицетворяющей систему хищнической эксплуатации отдельных народов. В условиях Евразии, для которой характерна крайняя пестрота составляющих ее геоэкономических ландшафтов и транзитных пространств, поддерживать ситуацию всеобщего устойчивого развития, что необходимо для мирного освоения и развития континента, крайне сложно и единственным долгосрочным решением ситуации здесь представляется 
постоянное авторитетное согласование развития различных регионов континента на разных скоростях - экономических, финансовых, культурных и юридических. Ориентация на такую политику предполагает налаживание универсального институционального механизма согласования интересов и возможностей отдельных эколандшафтов, регионов и транзитных пространств в рамках совместных интересов долгосрочного устойчивого развития. Этим целям, собственно говоря, и должно служить дальнейшее развитие континентальной правовой и политической (геополитической) традиции во всех ее модусах [Бабурин 2005:651].

Активизация восточного вектора евразийской политики России связана с ее активным участием в региональной юридической глобализации на азиатском направлении. Безусловно, наиболее высокого уровня юридическая глобализация достигла в Европе, но эта общемировая тенденция постепенно охватывает и азиатский континент. Наглядным показателем этого является как возрастающая роль стран Азии в мировой политике, так и интеграционные процессы внутри региона: создание Шанхайской организации сотрудничества (ШОС), Евразийского экономического сообщества (ЕврАзЭС), Евразийского экономического союза (ЕАЭС), создание Азиатско-Тихоокеанского экономического сотрудничества (АТЭС), активизация АСЕАН и т. д. Так, по итогам 2020 г. в совместном коммюнике глав правительств государств - членов ШОС была отмечена важность использования потенциала стран региона, международных организаций и многосторонних объединений в интересах формирования в Евразии пространства широкого, открытого, взаимовыгодного и равноправного взаимодействия в соответствии с нормами международного права, прежде всего, принципами равноправия, взаимного уважения и учета национальных интересов. В очередной раз была отмечена инициатива Российской Федерации о создании Большого Евразийского партнерства с участием стран Шанхайской организации сотрудничества, Евразийского экономического союза, Ассоциации государств Юго-Восточной Азии, а также других заинтересованных госу- дарств и многосторонних объединений․

Немаловажную роль играет сотрудничество России с АCEAH; в 2021 г. будет отмечаться 25-летие диалогового партнерства. По итогам состоявшегося в ноябре 2018 г. в Сингапуре саммита Россия - ACEAН было принято важное решение о повышении партнерства Россия - АСЕАН до стратегического уровня, а также был подписан Меморандум о сотрудничестве между Евразийской экономической комиссией и АCEAН, что заложило основу для обсуждения перспектив создания зоны свободной торговли в формате ЕАЭС - АСЕАН. Налажен регулярный диалог между Секретариатами ШОС и АСЕАН ${ }^{9}$.

Таким образом, задача внешнеполитического курса России - обеспечить участие в глобализации на базе евразийства, реализовать в первую очередь интересы своего многонационального народа, а также стран евразийского мира, задача же юристов - ответить на вопрос: каким образом российскому государству выстроить наиболее оптимальную систему правоотношений с азиатским странами, их организациями? Необходимо также создать соответствующую законодательную базу для обеспечения экономического, политического и гуманитарного сотрудничества.

Изменение вектора во внешней политике требует соответствующего правового оформления на уровне международно-правовых, межгосударственных документов, правительственных и межправительственных решений, межведомственных соглашений, договоров о межрегиональном сотрудничестве территорий. Создание этого многоуровневого международно-правового механизма невозможно без глубокого знания особенностей правовой семьи, национального законодательства, правовой культуры, обычаев и правовых традиций стран Азии, вовлеченных в орбиту сотрудничества с Россией на многосторонней и двусторонней основе [Molchanov 2018:510-511].

Важнейшим фактором, определяющим необходимость резкой активизации юридических исследований правовых систем и институтов стран Азии, являются потребности правового обеспечения бурно растущего экономического сотрудничества. Согласно официальной россий-

\footnotetext{
8 Шанхайская организация сотрудничества: Совместное коммюнике по итогам XIX заседания Совета глав правительств (премьер-министров) государств - членов ШОС. Доступ: http://rus.sectsco.org/news/20201130/696046.html (дата обращения: 14.12.2020).

9 Министерство иностранных дел Российской Федерации: Диалоговое партнерство Россия - АСЕАН. Доступ: https:// asean.mid.ru/dialogovoe-partnerstvo (дата обращения: 14.12.2020).
} 
ской позиции, Азия считается «локомотивом» мировой экономики ${ }^{10}$. Россия производит перераспределение потоков энергетических ресурсов из Европы в Азию (проекты «Сахалин-І» и «Сахалин-II», строительство нефтепровода Восточная Сибирь - Тихий океан [СВСТО], проектирование и строительство газопроводов «Алтай», «Сила Сибири»). Расширяется сотрудничество с КНР: двусторонний товарооборот с Китаем в 2018 г. превысил 107 млрд долл. В 2015 г. стороны подписали совместное заявление о сотрудничестве по сопряжению строительства Евразийского экономического союза и «Экономического пояса Шелкового пути». При этом китайская сторона заявила о поддержке активных усилий России к продвижению интеграционных процессов в рамках Евразийского экономического союза (ЕАЭС) и о начале переговоров с ним о заключении соглашения о торгово-экономическом сотрудничестве. С Японией и Южной Кореей заключен ряд взаимовыгодных торгово-экономических контрактов, достигнуты соглашения об инвестировании Россией значительных ресурсов в газо- и нефтедобычу Индонезии и т. д.

Географическое положение России, размеры ее территории, уже существующая и планируемая инфраструктура объективно делают нашу страну связующим звеном, своеобразным транспортным мостом между Европой и Азией. Транзитные коммуникации России - это не только кратчайшее расстояние для доставки грузов. Не менее важным их преимуществом является то, что в этом случае основную часть пути грузы проходят через единое административное пространство, пересекают наименьше число границ. Bсе это упрощает транзитные процедуры, сокращает время и документооборот, связанный с перевозкой, а следовательно, значительно экономит средства грузоотправителей и грузополучателей.

Дальнейшее развитие транспортной инфраструктуры России связывается прежде всего с созданием целостной мультимодальной транспортной сети, основу которой составляют евроазиатские транспортные коридоры. Крупным шагом в развитии транспортной инфраструктуры Азиатско-Тихоокеанского региона стал Делийский план действий по развитию инфраструк- туры ATP на 1997-2006 гг., поддержанный Россией. Наша страна приняла участие в 31 проекте в рамках этапа Делийского плана, в том числе в 25 проектах по транспорту. Их реализация, несомненно, будет способствовать развитию торгово-экономических связей между странами АТР и остальным миром.

Одна из главных задач России - развитие транспортной системы Сибири и Дальнего Востока. Этим объясняется интерес нашей страны к большинству транспортных проектов, реализуемых под эгидой ООН. В первую очередь следует отметить проект Комплексного развития инфраструктуры наземного транспорта в Азии, в реализации которого наиболее активно участвует Россия. Его конечной целью является интегрированная азиатская сеть наземного транспорта, а также обеспечение евроазиатских транспортных связей. Дальнейшая реализация этого проекта предполагает согласование автомобильных, железнодорожных и автомобильно-железнодорожных маршрутов Азиатской шоссейной дороги (АШД) и Трансазиатской железной дороги (ТАЖД), их формализацию, в том числе и на основе разработки соответствующих международных соглашений [Островский 2017:974-985].

Специализированные учреждения ООН в области транспорта поддержали российскую инициативу по разработке проекта Соглашения по азиатским шоссейным дорогам, которые позволят формировать сеть основных азиатских дорог международного значения, состыковать азиатские дороги сети А с европейской сетью Е, в том числе в плане гармонизации целого ряда дорожных стандартов и процедур. С этой целью Россия в 2004 г. в Шанхае присоединилась к Межправительственному соглашению по сети азиатских автомобильных дорог, которое создает правовую основу для международной отраслевой интеграции, регламентирует деятельность государств при проведении дорожной политики, определяет основные требования к этой сети.

Россия потенциально могла бы переключить на себя значительную часть евразийских товарных потоков: при 50 \% российской доли в доходности транспортных систем доход составит 1,5-2,5 трлн долл. - сумму, превышающую объем ВВП. Сегодня Россия обслуживает не более

\footnotetext{
10 Министерство иностранных дел Российской Федерации: Доклад рабочей группы СГС РФ при МИД России по вопросам участия субъектов РФ в международных организациях. 2005. № 21-22. Доступ: https://www.mid.ru/activity/coordinating_and_advisory_body/meetings/-/asset_publisher/oOD4RcICOGw8/content/id/417130 (дата обращения: 12.12.2020).
} 
5-7 \% потенциального объема евразийского рынка транспортно-логистических услуг. Утверждение России как ключевого транспортнокоммунистического звена единой евразийской инфраструктуры позволило бы сблизить ее сырьевые и промышленные регионы, способствовало бы развитию производственных комплексов и социально-экономической сферы на обширных восточных территориях [Глазьев 2018:661-662].

Все сказанное требует первоочередного развития исследований по правовому обеспечению внешнеэкономической деятельности, подготовки специалистов в сфере таможенного, инвестиционного, налогового, торгового, предпринимательского права, хорошо ориентированных в национальном законодательстве экономической сферы азиатских стран.

Важные задачи российской юридической науки, науки международного права связаны с оптимизацией роли России в международных организациях, функционирующих на азиатскотихоокеанском направлении, с повышением эффективности их деятельности. Как уже отмечалось, Россия - полноправный член таких организаций, как Содружество Независимых Государств (СНГ), Евразийское экономическое сообщество (ЕврАзЭС), Евразийский экономический союз (ЕАЭС), Шанхайская организация сотрудничества (ШОС), Азиатско-Тихоокеанское экономическое сотрудничество (АТЭС). Кроме того, Россия активно участвует в работе регионального форума АCEAН по безопасности и азиатско-тихоокеанскому экономическому сотрудничеству. Очевидно, что нашей стране необходимо придерживаться единой стратегии в работе этих организаций, нужны скоординированность усилий наших представителей в них, правильное определение возможностей каждой организации в реализации внешнеполитических, экономических и правовых задач, стоящих перед Россией в странах Азии, а также обеспечение своей активной, инициативной роли в текущей деятельности организаций и т. д.

\section{Список литературы}

1. Бабурин С. Н. 2005. Мир империй. Территория государства и мировой порядок. СПб.: Юридический центр. $1060 \mathrm{c}$.

\section{6. Выводы}

Одна из задач российской юридической науки, науки сравнительного права, связана с разработкой нормативно-правовой базы для осуществления основных направлений деятельности соответствующих международных структур, чтобы их организационный механизм был гармонизирован с национальными правовыми системами.

Практическая реализация Россией евразийского проекта потребует внесения серьезных корректив и в дипломатическую, международную деятельность страны. Необходимо обеспечить разновекторность, баланс в дипломатической, политической, гуманитарной, правовой и иных сферах. Несмотря на гигантские дипломатические усилия, сотрудничество с ЕС и Западом продвигается противоречиво, реализация программы «Партнерство для модернизации» была увязана с требованиями реформирования правовой и судебной системы России ${ }^{11}$. Нашу страну и сейчас призывают «рубить окно» в Европу, поскольку без сотрудничества с ней Азия поглотит, растворит в себе Россию ${ }^{12}$. А в последнее время мы стали прямыми свидетелями деградации политики Запада по отношению к России, выразившейся в силовом, санкционном давлении на нашу страну. В целом же именно евразийская концепция позволит нашей стране выбрать свой, российский путь развития, обеспечивающий преломление собственного и мирового опыта через призму отечественной истории, через позитивный творческий традиционализм, предлагающий глубокие и последовательные реформы в атмосфере соборности, духовной общности, социально-психологического, экономического, политико-правового единения самых различных слоев российского общества [Бабурин 2005:601]. При этом никто не призывает забыть об активной политике на европейском континенте. Однако существует настоятельная необходимость преодоления явного крена во всех сферах российской жизни в сторону сотрудничества с Европой и Северной Америкой в ущерб азиатскому направлению, что явно противоречит евразийской парадигме развития России.

2. Бжезинский 3. Б. 1998. Великая шахматная доска. М.: Международные отношения. 112 с.

3. Бжезинский 3. Б. 2008. Выбор: мировое господство или глобальное лидерство. М.: Международные отношения. 288 с.

\footnotetext{
11 Кузьмин В. Прорубить визу в Европу. - Российская газета. 2.06.2010.
}

12 Кузьмин В. В Европу за партнерством. - Российская газета. 5.06.2008. 
4. Бордачев Т.В., Пятачкова А.С. 2018. Концепция «Большой Евразии» в повороте России на Восток. - Вестник международных организаций. Т. 13. № 3. С. 33-51. DOI: 10.17323/1996-7845-2018-03-02

5. Буянов В. С. 2009. «Русский мир» как глобальный край. - Вестник аналитики. № 3. С. 7-22.

6. Вылегжанин А.Н., Дудыкина И.П. 2016. Понятие «международно-правовая политика государства». Московский журнал международного права. № 4. С. 21-37.

7. Глазьев С. Ю. 2006. Социалистический ответ либеральной глобализации. - Политический класс. № 9. С. 7176.

8. Глазьев С. Ю. 2016. Мирохозяйственные уклады в глобальном экономическом развитии. - Экономика и математические методы. Т. 52. № 2. С. 3-29.

9. Глазьев С. Ю. 2018. Рывок в будущее. Россия в новых технологическом и мирохозяйственном укладах. М.: Книжный мир. 768 с.

10. Делягин М. Г. 2002. Наша задача - созидание российской цивилизации. Ключевые вопросы идеологии. Вестник аналитики. № 2. С. 28-39.

11. Дугин А. Г. 2008. Экономическая безопасность постсоветского пространства. - Вестник аналитики. № 3. С. 104-111.

12. Дугин А.Г. 1997. Евразийский триумф (послесловие в книге П.Н. Савицкого «Континент Евразия»). М.: Аграф. C. 247-259.

13. Иванова Е.В. 2007. Анализ кризиса политической культуры (социально-философский аспект). - Международная безопасность России в условиях глобализации. Под общ. ред. В.А. Михайлова, В.С. Буянова. М.: РАГС. С. 377-383.

14. Кендердайн Т. 2020. Евразийство и постсоветская политическая география. - Вестник МГИМОУниверситета. Т. 13. № 4. С. 258-268. DOI: https://doi. org/10.24833/2071-8160-2020-4-73-258-268

15. Мартышин О. В. 2016. Частные, национальные и глобальные интересы: коллизия нравственных ценностей. - Государство и право. № 12. С. 25-31.

16. Нарочницкая Н., Мяло К. 1995. Еще раз о евразийском соблазне. - Наш современник. № 4. С. 128-137.

17. Овчинников А.И., Овчинникова С. П. 2002. - Евразийское правовое мышление Н.Н. Алексеева. Ростов-наДону: СКНЦ ВШ. 264 с.

18. Островский А.В. 2017. Перспективы сопряжения проектов экономического пояса Шелкового пути и Евразийского экономического союза. - Вестник Российской академии наук. T. 87. № 11. C. 974-985. DOI: 10.7868/ S0869587317110020.

19. Россия на пороге XXI века (современные проблемы наиионально-государственного строительства РФ). Под общ. ред. В. Н. Кожемякина, А. И. Подберезкина. 1996. М.: Обозреватель. 334 с.

20. Русская доктрина (Сергиевский проект). Под общ. ред. А. Б. Кобякова, В. В. Аверьянова. 2008. М.: Яуза-Пресс. 862 c.

21. Савицкий П. Н. 1997. Континент Евразия. М.: Аграф. $461 \mathrm{c.}$

22. Титаренко М. Л. 1998. Россия лицом к Азии. М.: Республика. 320 с.

23. Трубецкой Н. С. 2015. Европа и человечество. М.: Директ-Медиа. 113 с.

24. Хаусхофер К. 2001. О геополитике: работы разных лет. М.: Мысль. 426 с.
25. Якунин В.И. [и др.]. 2012. Национальная идея России: коллективная монография. М.: Научный эксперт. $4439 \mathrm{c}$.

26. Arbatova N.K. 2019. Three Faces of Russia's NeoEurasianism. - Survival. Vol. 61. Issue 6. P. 7-24. DOI: 10.1080/00396338.2019.1688562.

27. Kazharski A. 2013. Eurasian Regionalism as an Identitary Enterprise: Representations of European Other in Russian Discourse on Eurasian Integration. - The Centre for EURussia Studies (CEURUS) EU-Russia Paper. 30 p. URL: http:// ceurus.ut.ee/wp-content/uploads/2011/06/EU-Russiapapers-12_Kazharski.pdf (accessed 18.12.2020).

28. Lagutina M. 2014. Eurasian Economic Union Foundation: Issues of Global Regionalization. - Eurasia Border review. Vol.5. No 1. P. 95-113.

29. Molchanov M. A. 2018. New regionalism and Eurasia. Handbook of Politics in Asia. London; New York: Routledge. P. 506-521.

30. Podadero P., Garashchuk, A. 2017. The Eurasian Economic Union and its potential relationship with the European Union. - Revista Universitaria Europea. No. 26. P. 37-54.

31. Robinson P.F. 2020. Russia's Emergence as an International Conservative Power. - Russia in Global Affairs. Vol. 18. No. 1. P. 10-37. DOI: 10.31278/1810-6374-2020-18-1-10-37.

32. The Law and Policy of New Eurasian Regionalization. Ed. by A. Aseeva, J. Gorski. 2021. Leiden;Boston: Martinus Nijhoff Publishers. 650 p. DOI: https://doi. org/10.1163/9789004447875

\section{References}

1. Arbatova N.K. Three Faces of Russia's Neo-Eurasianism. Survival. 2019. Vol. 61. Issue 6. P. 7-24. DOI: 10.1080/00396338.2019.1688562.

2. Baburin S. N. Mir imperii. Territoriya gosudarstva i mirovoi poryadok [The world of empires. The territory of the state and the world order]. Saint Petersburg: Yuridicheskii tsentr Publ. 2005. 1060 p. (In Russ.)

3. Bordachev T.V., Pyatachkova A.S. Kontseptsiya «Bol'shoi Evrazii» v povorote Rossii na Vostok [The Concept of Greater Eurasia in the Turn of Russia to the East]. - International Organizations Research Journal. 2018. Vol. 13. No. 3. P. 33-51. (In Russ.). DOI: 10.17323/1996-7845-2018-03-02

4. Brzezinski Zb. The Choice: Global Domination or Global Leadership (Russ. ed.: Brzezinski Zb. Vybor: mirovoe gospodstvo ili global'noe liderstvo. Moscow: Mezhdunarodnye otnosheniya Publ. 288 p.)

5. Brzezinski Zb. The Grand Chessboard: American Primacy and Its Geostrategic Imperatives (Russ. ed.: Brzezinski Zb. Velikaya shakhmatnaya doska. Moscow: Mezhdunarodnye otnosheniya Publ. 1998. 112 p.)

6. Buyanov V. S. "Russkii mir" kak global'nyi krai ["Russian world" as a global region]. - Vestnik analitiki. 2009. No. 3. P. 7-22. (In Russ.)

7. Delyagin M. G. Nasha zadacha - sozidanie rossiiskoi tsivilizatsii. Klyuchevye voprosy ideologii [Our task is the creation of Russian civilization. Key issues of ideology]. - Vestnik analitiki. 2002. No. 2. P. 28-39. (In Russ.)

8. Dugin A. G. Ekonomicheskaya bezopasnost' postsovetskogo prostranstva [Economic security of the post-Soviet space]. - Vestnik analitiki. 2008. No. 3. P. 104-111. (In Russ.)

9. Dugin A.G. Evraziiskii triumf (posleslovie v knige P.N. Savitskogo «Kontinent Evraziya») [Eurasian triumph (afterword 
in P.N. Savitsky's book "Continent Eurasia")]. Moscow: Agraf Publ. 1997. P.433-455. (In Russ.)

10. Glaziev S. Yu. Mirokhozyaistvennye uklady v global'nom ekonomicheskom razvitii [National Economy Structures in the Global Economic Development]. - Ekonomika $i$ matematicheskie metody. 2016. Vol. 52. No. 2. P. 3-29. (In Russ.)

11. Glaziev S. Yu. Ryvok v budushchee. Rossiya v novykh tekhnologicheskom i mirokhozyaistvennom ukladakh [A leap into the future. Russia in new technological and world economic ways]. Moscow: Knizhnyi mir Publ. 2018. 768 p. (In Russ.)

12. Glaziev S. Yu. Sotsialisticheskii otvet liberal'noi globalizatsii [Socialist response to liberal globalization]. - Politicheskii klass. 2006. No. 9. P. 71-76. (In Russ.)

13. Haushofer K. O geopolitike: raboty raznykh let [About Geopolitics: works of different years]. Moscow: Mysl' Publ. 2001.426 p. (In Russ)

14. Ivanova E.V. Analiz krizisa politicheskoi kul'tury (sotsial'nofilosofskii aspekt) [Analysis of the crisis of political culture (socio-philosophical aspect)]. - Mezhdunarodnaya bezopasnost' Rossii v usloviyakh globalizatsii. Pod obshch. red. V.A. Mikhailova, V.S. Buyanova [International security of Russia in the context of globalization. Ed. by V.A. Mikhailov and V.S. Buyanov]. Moscow: RAGS Publ. 2007. P. 377-383. (In Russ.)

15. Kazharski A. Eurasian Regionalism as an Identitary Enterprise: Representations of European Other in Russian Discourse on Eurasian Integration. - The Centre for EU-Russia Studies (CEURUS) EU-Russia Paper. 2013. 30 p. URL: http:// ceurus.ut.ee/wp-content/uploads/2011/06/EU-Russiapapers-12 Kazharski.pdf (accessed 18.12.2020).

16. Kenderdine T. Evraziistvo i postsovetskaya politicheskaya geografiya [Eurasianism and Post-Soviet Political Geography]. - MGIMO Review of International Relations. 2020. Vol. 13. No. 4. P. 258-268. (In Russ.) DOI: https://doi. org/10.24833/2071-8160-2020-4-73-258-268

17. Lagutina M. Eurasian Economic Union Foundation: Issues of Global Regionalization. - Eurasia Border review. 2014. Vol.5. No 1. P. 95-113.

18. Martyshin O. V. Chastnye, natsional'nye i global'nye interesy: kolliziya nravstvennykh tsennostei [Private, national, and global interests: conflicts of moral values]. - Gosudarstvo i pravo. 2016. No. 12. P. 25-31. (In Russ.)

19. Molchanov M. A. New regionalism and Eurasia. - Handbook of Politics in Asia. London; New York: Routledge. 2018. P. 506-521.

20. Narochnitskaya N., Myalo K. Eshche raz o evraziiskom soblazne [Once again about Eurasian temptation]. - Nash sovremennik. 1995. No. 4. P. 128-137. (In Russ.)
21. Ostrovskii A.V. Perspektivy sopryazheniya proektov ekonomicheskogo poyasa Shelkovogo puti i Evraziiskogo ekonomicheskogo soyuza [Prospects to interface the Silk Road Economic Belt and the Eurasian Economic Union projects]. - Herald of the Russian Academy of Sciences. 2017. Vol. 87. No. 11. P. 974-985 (In Russ.). DOI: 10.7868/ S0869587317110020

22. Ovchinnikov A.l., Ovchinnikova S. P. Evraziiskoe pravovoe myshlenie N.N. Alekseeva [Eurasian Legal Ideas of N.N.Alexeyev]. Rostov-on-Don: SKNTs VSh Publ. 2002. 264 p. (In Russ.)

23. Podadero P., Garashchuk, A. 2017. The Eurasian Economic Union and its potential relationship with the European Union. - Revista Universitaria Europea. 2018. No. 26. P. $37-$ 54.

24. Robinson P.F. Russia's Emergence as an International Conservative Power. - Russia in Global Affairs. 2020. Vol. 18. No. 1. P. 10-37. DOI: 10.31278/1810-6374-2020-181-10-37.

25. Rossiya na poroge XXI veka (sovremennye problemy natsional'no-gosudarstvennogo stroitel'stva RF). Pod obshch. red. V. N. Kozhemyakina, A. I. Podberezkina [Russia is on the verge of the 21st century (modern problems of national-state construction of the Russian Federation). Ed. by V.N. Kozhemyakin, A.I. Podberezkin]. M.: Obozrevatel Publ. 1996. 334 p. (In Russ.)

26. Russkaya doktrina (Sergievskii proekt). Pod obshch. red. A. B. Kobyakova, V. V. Aver'yanova [Russian doctrine (Sergius project). Ed. by A.B. Kobyakov, V.V. Averyanov]. Moscow: Yauza-Press Publ. 2008. 862 p. (In Russ.)

27. Savitskii P. N. Kontinent Evraziya [Continent Eurasia]. Moscow: Agraf Publ. 1997. 461 p. (In Russ.)

28. The Law and Policy of New Eurasian Regionalization. Ed. by A. Aseeva, J. Gorski. Leiden; Boston: Martinus Nijhoff Publishers. 2021. 650 p. DOI: https://doi. org/10.1163/9789004447875

29. Titarenko M. L. Rossiya litsom k Azii [Russia facing Asia]. Moscow: Respublika Publ. 1998. 320 p. (In Russ.)

30. Trubetskoi N. S. Evropa i chelovechestvo [Europe and Humanity]. Moscow: Direkt-Media Publ. 2015. 113 p. (In Russ.)

31. Vylegzhanin A.N., Dudikina I.P. Ponyatiye "mezhdunarodno-pravovaya politika gosudarstva" [The Politics of International Law as a Concept]. - Moscow Journal of International Law. 2016. No. 4. P. 21-37 (in Russ.)

32. Yakunin V.I. [et al.]. Natsional'naya ideya Rossii: kollektivnaya monografiya [National Idea of Russia: a collective monograph]. Moscow: Nauchnyi ekspert Publ. 2012. 4439 p. (In Russ.)

\section{Информация об авторе}

\section{Юрий Ильич Скуратов,}

Заслуженный юрист Российской Федерации, доктор юридических наук, профессор,заведующий кафедрой национального публичного и международного права, Российский государственный социальный университет

129226, Российская Федерация, Москва, ул. Вильгельма Пика, д. 4-1

skuratov_yi@mail.ru

ORCID: 0000-0002-2126-2005

\section{About the Author}

\section{Yuri I. Skuratov,}

Honored Lawyer of the Russian Federation, Doctor of Juridical Sciences, Professor, Head of the Department of National Public and International Law, Russian State Social University

4-1, ul. Wilhelma Pika, Moscow, Russian Federation, 129226

skuratov_yi@mail.ru

ORCID: 0000-0002-2126-2005 